\title{
Capturing and Characterising Notional Machines
}

\author{
Citation for published version (APA):
}

Fincher, S., Jeuring, J., Miller, C. S., Donaldson, P., Boulay, B. D., Hauswirth, M., Hellas, A., Hermans, F., Lewis, C. M., Mühling, A., Pearce, J. L., \& Petersen, A. (2020). Capturing and Characterising Notional Machines. In M. N. Giannakos, G. Sindre, A. Luxton-Reilly, \& M. Divitini (Eds.), Proceedings of the 2020 ACM Conference on Innovation and Technology in Computer Science Education: ITiCSE 2020 (pp. 502-503). acm. https://doi.org/10.1145/3341525.3394988

DOI:

$10.1145 / 3341525.3394988$

Document status and date:

Published: 01/06/2020

Document Version:

Publisher's PDF, also known as Version of record

Document license:

Taverne

Please check the document version of this publication:

- A submitted manuscript is the version of the article upon submission and before peer-review. There can be important differences between the submitted version and the official published version of record. People interested in the research are advised to contact the author for the final version of the publication, or visit the DOI to the publisher's website.

- The final author version and the galley proof are versions of the publication after peer review.

- The final published version features the final layout of the paper including the volume, issue and page numbers.

Link to publication

\section{General rights}

Copyright and moral rights for the publications made accessible in the public portal are retained by the authors and/or other copyright owners and it is a condition of accessing publications that users recognise and abide by the legal requirements associated with these rights.

- Users may download and print one copy of any publication from the public portal for the purpose of private study or research.

- You may not further distribute the material or use it for any profit-making activity or commercial gain

- You may freely distribute the URL identifying the publication in the public portal.

If the publication is distributed under the terms of Article 25fa of the Dutch Copyright Act, indicated by the "Taverne" license above, please follow below link for the End User Agreement:

https://www.ou.nl/taverne-agreement

Take down policy

If you believe that this document breaches copyright please contact us at:

pure-support@ou.nl

providing details and we will investigate your claim.

Downloaded from https://research.ou.nl/ on date: 26 Apr. 2023 


\section{Capturing and Characterising Notional Machines}

\author{
Sally Fincher (co-leader) \\ School of Computing \\ University of Kent \\ Canterbury, Kent, UK \\ S.A.Fincher@kent.ac.uk \\ Peter Donaldson \\ Computing Science \\ University of Glasgow \\ Glasgow, Scotland, UK \\ peter.donaldson.2@glasgow.ac.uk \\ Arto Hellas \\ Department of Computer Science \\ Aalto University \\ Espoo, Finland \\ arto.hellas@aalto.fi \\ Andreas Mühling \\ Institute for Computer Science \\ Kiel University \\ Kiel, Germany \\ andreas.muehling@infomatik.uni- \\ kiel.de
}

\author{
Johan Jeuring (co-leader) \\ Department of ICS \\ Utrecht University \\ The Netherlands \\ J.T.Jeuring@uu.nl
}

\author{
Benedict du Boulay \\ Department of Informatics \\ University of Sussex \\ Brighton, Sussex, UK \\ b.du-boulay@sussex.ac.uk
}

\author{
Felienne Hermans \\ LIACS \\ Leiden University \\ The Netherlands \\ f.f.j.hermans@liacs.leidenuniv.nl
}

Janice L. Pearce

Computer Science Department

Berea College

Berea, KT, USA

pearcej@berea.edu

\author{
Craig S. Miller (co-leader) \\ School of Computing \\ DePaul University \\ Chicago, IL, USA \\ cmiller@cs.depaul.com
}

\author{
Matthias Hauswirth \\ Faculty of Informatics \\ USI Università della Svizzera italiana \\ Lugano, Switzerland \\ matthias.hauswirth@gmail.com
}

Colleen Lewis

Department of Computer Science

Harvey Mudd College

Claremont, CA, USA

lewis@cs.hmc.edu

\author{
Andrew Petersen \\ Department of ICS \\ University of Toronto \\ Toronto, Canada \\ andrew.petersen@utoronto.ca
}

\begin{abstract}
A notional machine is a pedagogic device to assist the understanding of some aspect of programs or programming. It is typically used to support explaining a programming construct, or the user-understandable semantics of a program. For example, a variable is like a box with a label, and assignment copies or moves a value into that box.

This working group will capture examples of notional machines from actual pedagogical practice, as expressed in textbooks (or other teaching materials) or used in the classroom. We will interview at least 30 teachers about their experience with, and perceptions of, the use of notional machines in teaching. Using the interviews, we will work on devising and refining a form to characterise essential features of notional machines. We will also attempt to relate them to each other to describe potential Capturing and Characterising Notional Machines Sally Fincher, Johan Jeuring, Craig S Miller

Permission to make digital or hard copies of part or all of this work for personal or classroom use is granted without fee provided that copies are not made or distributed for profit or commercial advantage and that copies bear this notice and the full citation on the first page. Copyrights for third-party components of this work must be honored. For all other uses, contact the Owner/Author. ITiCSE '20, June 15-19, 2020, Trondheim, Norway

(C) 2020 Copyright is held by the owner/author(s).

ACM ISBN 978-1-4503-6874-2/20/06.

https://doi.org/10.1145/3341525.3394988
\end{abstract}

learning sequences or progressions. The working group report will contain descriptions of notional machines used at different levels in education, in different countries, by many teachers.

The resulting catalogue of notional machines will allow a teacher to select a machine for a particular use, permit comparison between them, and provide a starting point for further categorization and analysis of notional machines.

Additionally, we will make more theoretical explorations. We will explore a variety of presentational formats, examining what is necessary and what superfluous; we will look for dimensions of comparison and will examine how notional machines are instantiated across the discipline. We argue that the creation and use of notional machines is potentially a signature pedagogy for computing [1] and that creating and using notional machines represents a certain level of pedagogic sophistication that might be an indicator of pedagogic content knowledge (PCK).

CCS CONCEPTS: Applied Computing. Education

\section{KEYWORDS}

Notional machines, pedagogical practice, signature pedagogies, PCK 


\section{What is a Notional Machine?}

First identified by du Boulay [2,3,4] a notional machine is a pedagogic device to assist the understanding of some aspect of programs or programming. It is normally associated with teaching novices, but can also be applied in other teaching or training situations with more expert participants. It is called "notional" in the sense that what is being described is a simplified, partially true, version of the truth. It is called a "machine" because it describes both entities and their actions. For example, a variable is like a box with a label, and assignment copies/moves a value into that box.

A notional machine is not a mental representation in itself, although learners will develop an understanding of the computer and programming, and that understanding may well be influenced by any notional machines that they have been exposed to.

A crucial aspect of a notional machine is that it should simplify an actual concept or skill as an aid to understanding. It should also encompass the associated epiphenomena of programs and programming, such as the names of program constructs, the causes and content of error messages, the names on buttons in the environment (e.g. "save", "file" etc), the locations of files containing programs, the difference between editing and running a program and so on.

For a beginner faced with learning how to design, code, test and debug programs, there are three areas in which a notional machine may play a role.

- The programming environment in which the program-ming is to be undertaken. This includes the file system and tools for coding, editing and debugging.

- The programming language itself. This includes the basic constructs of the language as well as any built-in language features for aggregating small chunks of code into larger units.

- The tasks of programming, where the human, in a way, acts as a "machine" undertaking actions such as coding, debugging, editing and testing.

\section{Preliminary work}

The proposal for this working group originates from Dagstuhl seminar 19281, Notional Machines and Programming Language Semantics in Education, 7th-12th July 2019. At this seminar, a subgroup was formed to gather and examine practical examples of notional machines. The small corpus collated there provides preliminary work for the working group, and includes the following:

- An interview protocol for eliciting notional machines.

- A collection of more than 10 interview recordings and transcriptions.

- A rough working set of attributes to describe (and potentially help classify) notional machines.

\section{Objectives of this Working Group}

This group has four objectives:

(a) To conduct a literature review, to ground and inform the work;

(b) To capture examples of notional machines in use;

(c) To catalogue them in a common scheme; and,

(d) To arrange them in clusters or sequences.

The outputs of the working group will form the first contextualized collection of notional machines from multiple sources. We anticipate that it will not only provide a useful collection for teachers, but also a foundational resource for other researchers interested in this area [5] [6].

\section{ACKNOWLEDGMENTS}

This work builds on initial activity undertaken at Dagstuhl seminar 19281, Notional Machines and Programming Language Semantics in Education, $7^{\text {th }}-12^{\text {th }}$ July 2019. The three organizers of this working group participated in the Dagstuhl seminar.

\section{REFERENCES}

[1] Shulman, L. (2005) Signature Pedagogies in the Professions Daedalus, 134(3), 5259

[2] du Boulay, B. (1986). Some difficulties of learning to program. Fournal of Educational Computing Research, 2(1), 57- 73.

[3] du Boulay, B., \& O'Shea, T. (1981). Teaching novices programming. In M. J. Coombs \& J. L. Alty (Eds.), Computing Skills and the User Interface (pp. 147200). Cambridge, MA: Academic Press.

[4] du Boulay, B., O'Shea, T., \& Monk, J. (1981). The black box inside the glass box: presenting computing concepts to novices. International fournal of ManMachine Studies, 14(3), 237-249.

[5] Sorva. Juha (2013). Notional machines and introductory programming education. ACM Trans. Comput. Educ. 13, 2, Article 8 (July 2013), 31 pages. DOI:https://doi.org/10.1145/2483710.2483713

[6] Berry, Michael (2015) The Design and Implementation of a Notional Machine for teaching Introductory Programming, $\mathrm{PhD}$ thesis, University of Kent 